\title{
FEATURE
}

\section{Meaning in the Use of Freedom}

\section{The Free Press Underground, the University of Missouri, and Students for a Democratic Society}

\section{Author_Chris Drew(cad6174@gmail.com), MLIS student, University of Missouri; department manager, Schweitzer Brentwood Branch, Springfield Greene County Library}

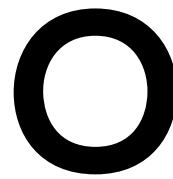

$\mathrm{n}$ the morning of February 19, 1969, four students set up shop at the Student Union on the Columbia campus of the University of Missouri (MU). They were selling their newspaper, the Free Press Underground, and other assorted papers from the leftist small press industry that was burgeoning in the late 60s (Allain, Castagna, and DeHart 1970, 695). These publications, specifically that day's edition of the Free Press Underground, contained what Dean of Students Jack Matthews (1969c) would later refer to as obscene, vulgar, indecent, and pornographic words and images.

Matthews confronted the students early and had them removed with the assistance of campus police. The students continued to sell their publications on the public sidewalk off campus. They were soon arrested there by Boone County Sheriff's deputies and charged with having "unlawfully, intentionally and knowingly offered for sale and had in their possession with intent to sell or circulate an obscene, lewd, licentious, indecent and lascivious paper, to-wit: Underground Free Press" (Miller 1969, 1). The title of the newspaper, again, was the Free Press Underground.

As an act of speech, this newspaper's publication and distribution represented the key document and action over which a protracted First Amendment legal battle began that would make its way to the Supreme Court. It also represents a material example of the cultural wars of the era and the escalation of confrontation between student activists and university administrators. Understanding the events surrounding the arrest of these students means understanding the loose organization that published the offending paper, the administrators who attempted to ban it, and the dynamics of their relationship. It also means understanding the broader history, the national social climate of the late $60 \mathrm{~s}$, and the worldviews that came to a head that day. The value of this understanding is a fully contextualized picture of a seminal event in information freedom that might inform our understanding of contests over the freedom of expression and censorship today. In particular, this perspective may exemplify the deeper historical motives and contexts of a speech act starkly remembered for its obscenity and legal precedent but largely divorced from real life and what it meant to its publishers and audience at the time. 
A study of the documentation of the events surrounding the arrests as they appeared in daily news, MU communications, and the alternative press presents not just a timeline, but the meaning of the speech act to those involved and the intersection of some of the powers and actors that moved all involved parties toward the conclusion.

\section{Case}

The Free Press Underground was a derivative of an earlier paper titled the Columbia Free Press, published by some of the same students. That paper appeared in 1966, alongside the university's chapter of the Students for a Democratic Society (SDS) - a local branch of one of the largest American socialist organizations of the era (Smith and Smith 2018, 207). The staff of the Free Press Underground was largely composed of MU SDS members and affiliates who covered and commented on local news and advocated for socialist and otherwise radical positions and perspectives. Topics in the publication included democratized student control of the university, an end to the war in Vietnam, and inroads in fights against perceived sexist and racist discrimination. It also published local and outsourced feature articles, art, and poetry.

SDS members at the university regularly printed and distributed the Free Press Underground under various titles in the late 1960s. They also distributed SDS national publications like The New Left Notes and radical publications from other cities like the Bay Area newspaper The Movement ("SDS Ousted From Union" 1969, 1). The two most incendiary pieces in that February 19 copy of the Free Press Underground were, in fact, reprinted from these two publications, with citations.

The most divisive piece, a cartoon depicting the rape of Ladies Liberty and Justice by police officers, came from The Movement. It was recontextualized in the Free Press Underground, as in its initial run it was printed as a "poster" beside an editorial in The Movement following the indictment of the Oakland Seven. The Seven had been arrested for interfering with the business of an Oakland draft office. The author of the editorial noted "surely it's illegal to block an induction center, so it must be illegal to

\section{INTELLECTUAL 드는

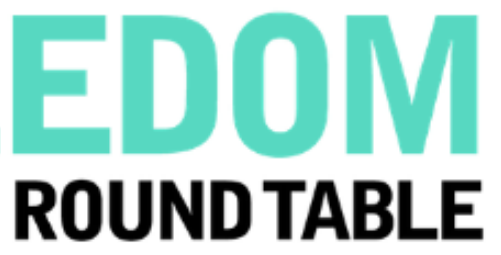

IFRT offers the opportunity for greater involvement in defending intellectual freedom.

Become a member for only $\$ 15$ a year.

Join: ala.org/membership

Engage: ala.org/ifrt

(ソ@IFRT_ALA $\boldsymbol{f}$ IFRTALA

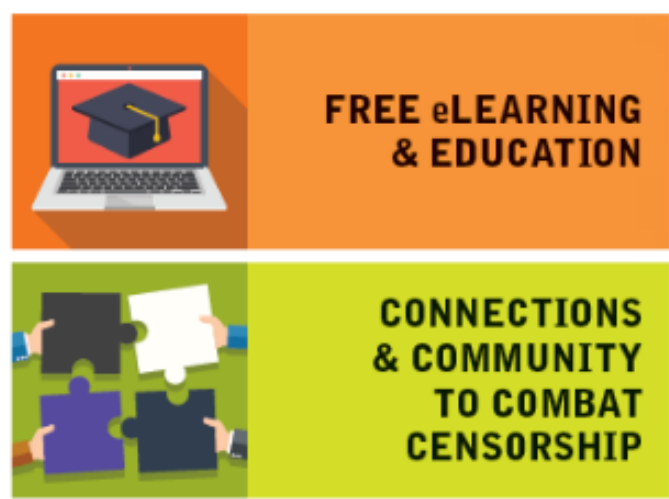

RECOGNITION OF PROFESSIONAL ACHIEVEMENT THROUGH AWARDS

\title{
"LIBRARIES SHOULD CHALLENGE CENSORSHIP IN THE FULFILLMENT OF THEIR RESPONSIBILITY TO PROVIDE INFORMATION AND ENLIGHTENMENT."
}

\author{
Library Bill of Rights
}


conspire to do so ... but they don't belong in jail, so the law must be wrong" (Cieciorka and Garson 1969, 3). In the Free Press Underground the image ran on the front page beneath the headline "Banned in the M.U. Union."

The other contentious content was an article on the acquittal of assault and battery of Ben Morea, member of the anarchist artist collective "Up Against the Wall Motherfucker." It was taken word for word from The New Left Notes, including the headline "Motherfucker Acquitted" (Free Press Underground February 13, 1969, 2).

This evocative use of image and language, regardless of its source, and regardless of whether it had been circulated before, would be the last straw in an ongoing conflict. The legacy of that conflict compounded the tensions surrounding this particular paper on this particular day. The paper and its distributors had already been banned once, just a week earlier. The "obscene" art beneath the headline "Banned in the M.U. Union" on February 19 was a direct reference to this incident on the February 12.

On February 12, Free Press Underground and SDS students had been asked to leave the MU Student Union for distributing the original publications containing the "obscene" content that they would later reprint. They returned the next day. Dean Matthews, with whom they were familiar, approached and delivered a prepared statement before having them removed again (Steele 1969, 5). Arrangements were made by Matthews for the leadership of SDS to appear before the Faculty Committee on Student Organizations, Government and Activities to discuss potential violations to university bylaws (Matthews 1969b). Less than a week later, before that meeting could take place, SDS premiered their February 19 issue in a clear statement to Dean Matthews and the university.

As Smith and Smith (2018) detail in their account of this event, that morning as "the publishers of the Free Press Underground had almost certainly anticipated, if not hoped, the campus and city authorities responded by confiscating copies of the paper and arresting some of the people handing it out on charges of distributing obscene material" (208).

The ensuing fallout saw the university struggle to decided on an appropriate reaction, facing public criticism on one side from lawmakers, Board of Curator members, and an avalanche of alumni letters hoping for swift retribution; and on the other side from the MU chapter of the American Association of University Professors, the Student Senate, the MU newspaper The Maneater, and the Committee of Concerned Students supporting the SDS.

In an initial slap on the wrist by the Faculty Committee on Student Organizations, Government and Activities, the SDS was not tangibly punished. The committee stated they believed university rules allowed for divisive content in all forms:

\footnotetext{
It is only by the collision of adverse opinions that an approximation of the truth is likely. As evidence of the University's adherence to this posture, our speaker's policy permits an unlimited latitude to student organizations to hear even the most unpopular of views. We can maintain no less a posture with respect to distribution of literature.

We must possess the same confidence in the ability of our students to reject noxious literature as we have in their capacity to sort out the true from the false in presentations by outside speakers. (Faculty, 1969)
}

Dean Matthews (1969c) immediately petitioned Chancellor John Schwada to review this decision. He cited the distribution of New Left Notes and The Movement and previous grievances, such as the time the chapter planned to change its registered name to the "Richard Ichord Chapter" (a mockery of Missouri Eighth District Representative Richard Ichord, at the time leading a House Committee in investigating the SDS nationally). Matthews also cited excerpts from the "By-Laws of the Board of Curators" and "regulations for student organizations in the 68-69 M-Book," referencing the standards of morality and indecent conduct, and pointed to the SDS members' admission that they did distribute the publications as charged. He went on to criticize the Faculty Committee for refusing to determine whether the objectionable content was indecent, vulgar, obscene, and whether it reflected unfavorably on the university.

In response to this petition Chancellor Schwada chose to reverse the Faculty Committee's decision and withdrew recognition of the MU chapter of SDS, bringing two of the four students who had been arrested before a Student Conduct Committee on March 27, 1969. One of those students, Herb Markham, a freshman, was placed on probation for the rest of his academic career. The other, a graduate student named Barbara Papish, was expelled from the university ("Miss Papish is Expelled" 1969, 15).

An additional review by the university reinstated the SDS's official recognition on campus, and the Boone County Court issued a stern warning as a result of the original arrests, but Papish faced a legal battle, routed through the United States District Court for the Western District of Missouri and then eventually to the Supreme Court via appeal in 1973. The Supreme Court ruled in her favor and overturned the university's perceived right to expel her based on this incident. 
The case was a part of a wave of First Amendment trials in the late 60 s and early 70 s, coming to court just a few years after Tinker v. Des Moines Independent Community School District, the famous case that won students the right to wear black arm bands in silent protest of the war in Vietnam. The Papish case reflected the same sensibilities regarding the disruption of and the right to "pure" speech. The Papish ruling also explicitly references a case the Court had decided just one year prior, in 1972: Healy $v$. James. Therein the court had ruled in favor of an SDS chapter at Central Connecticut State that had been refused recognition on campus and "reaffirmed that "state colleges and universities are not enclaves immune from the sweep of the First Amendment.' . . no matter how offensive to good taste" ("Supreme Court" 1973).

The court found the content of SDS's newspapers at MU and their peaceful distribution to be constitutionally protected, and the official reason for Papish's expulsion was specifically based on the indecency of the content. Therefore the expulsion as punishment violated her First Amendment rights. The university could not prove any other motive for the expulsion. The dissenting judges emphasized the school's right to govern itself and delved into Papish's history of run-ins with the university, her grades, and her leisurely pace toward graduation; but these were deemed insufficient arguments ("Supreme Court" 1973).

The case would add a brick to the wall of precedent being set regarding the First Amendment on college campuses. It was notable in that it specifically focused on the motive of the university's response. They began to escalate, along with the SDS and Free Press Underground, at a turning point during a broader shift in consciousness following 1968. A year of assassinations, international protests, the Chicago DNC riot, Vietnam escalation, Richard Nixon's election, and J. Edgar Hoover's intense attacks on left-wing organizations would mark the end of much of the productive radical energy of the 60s, already carried over from the civil rights movement of the 50s (Heiderman 2018).

The goals and ambitions of the university and the students were brought to a head in an ideological battle over the First Amendment. In some ways the elevation of a speech act-in this case the publishing of a cartoon and foul language - to such a high trial diminishes the evidence of those motives and obfuscates the speech act itself behind an argument of offense or taste. Not simply about the right to speech, this incident evolved from an active struggle between MU and its chapter of SDS. It was rooted in ongoing confrontations over broader issues of student rights and governance of student space, and it was bolstered by university anxieties driven by national incidents like the student takeover of Columbia University. It was further fueled by public animosity from powerful figures. The conflict is representative of the struggles on campuses across the country, and in ways it is uniquely representative of the state of the nation, and perhaps Missouri and the University of Missouri.

\section{The Cartoon}

As a companion to the historical context of the event, it is first worth discussing the historical context of the central piece of "obscenity." In records of the time, and now in the MU Archive topical guide on the subject, the piece of art central to the dispute is referred to as a cartoon. In its original form, as published in The Movement, it was referred to as a poster. This small change of verbiage has significant implications, as each description carries different connotations. This is reflected in the manifestations of the artwork and in our memory of it.

The poster was designed to respond to criminal action brought against the Oakland Seven activists trying to stop the draft as a means to stop the war in Vietnam. This art was drawn for a specific purpose.

In the context of the draft, the war, and the battle over criminal justice in terms of jail time and court rulings, this detailed and graphic artwork is meant to be taken seriously. It is reasonable to consider it a diminution to refer to this image as a cartoon. While the staff of the Free Press Underground did not refer to it as such, their attempt at recontextualization positioned it to be viewed that way. The fact that the historical memory of this art has been dominated by its place in this free-speech incident tends to erase its earlier existence, which was in fact relevant to the Columbia free speech incident and the history of the radical anti-war movement of the era. At the same time, this recontextualization of the original art allowed it to have a new life, gave it cause to be remembered, and reflects the unique and disparate experiences of the late-60s Left as represented by the metropolitan west coast and the rural midwest. It is also worth noting that when the art first appeared in a publication circulated by the SDS students, they would have expected at least some others to understand their reference. The reference to the art as a "cartoon" is therefore reminiscent of the part any image might play as a meme, which may be defined academically as "units of culture-ideas, symbols, and practices that spread in a variety of forms through imitation and appropriation" (Silvestri 2018). 
In describing memes and their potential for a complex reading, Silvestri writes "layered meanings enable certain groups to dog-whistle one another by making in-group jokes and references. By drawing on particular cultural moments and shared reference points, memes become a form of "vernacular criticism"" (4002). In this case it may certainly be observed that this art was used as a form of "vernacular criticism." It represented an original publication the group was reprimanded for distributing and the new publication they would be reprimanded for distributing. It also represented the perceived injustices surrounding the draft and war, and their correlation with perceived lack of freedom, democracy, and tacit support for the war that extended to frustrations with university administration. This deeper historical reading becomes impossible when the reader is removed too far from the original material. The potential referential irony of the art as it appeared in the Free Press Underground becomes difficult to appreciate.

The problems of reducing the speech act central to this incident to its most shallow interpretation is akin to the problem of reducing the incident's lessons to the conditions under which one has the right to or to not speak. In an era, as now, where divergent opinions are expressed in layers of irony and rhetoric wound with varying degrees of sincerity, it is more useful to attempt a deep reading of what is being communicated in a controversial speech act than to simply rule on its right to exist or not. This can tell us much more about the parties involved, and their goals, than the broad stroke of whether they appreciate the freedom of speech.

\section{Historical Context}

This incident did not have to happen. It is not likely that the distribution of this particular edition of the paper would have had a considerably different effect on the student population from the SDS papers distributed on campus since 1966. The fact that it did, and the conditions under which it did, now invite some scrutiny and provide a window into how we have processed moments of protest-in particular, issues of free speech and the First Amendment. This event has been covered to a degree in "Chronicles of Discontent, Tribunes for Change Columbia and Its Underground Press in the Vietnam Era" by Smith and Smith in the Missouri Historical Review (2018), but only then as part of a larger discussion and without focus on the specifics and surrounding history. The SDS and the political Left of the era has been covered thoroughly in the past, for example by Sale in SDS: The Rise And Development Of The Students For A Democratic Society (1973) and more recently in Jacobin by Heideman in "Half the Way with Mau Zedong" (2018). The broader cultural shift of this era is well-represented in print, including in relatively recent popular history such as Kurlansky's 1968 (2003) and Perlstein's Nixonland: The Rise of a President and the Fracturing of America (2008). However, there is space within this conversation to consider the convergence of historical events on campus on February 19, 1969.

\section{SDS and University Administration}

Cited in the Supreme Court Case as a blow to Barbara Papish is her involvement in what would be known as the "University Day Incident" ("Supreme Court" 1973). It was one of the first incidents to raise the MU chapter of SDS to infamy in the eyes of the university. In 1967 Papish participated, with several SDS members, in setting up a table and distributing literature during an event on campus for high school students and parents. Prior to this, the chapter had been told repeatedly by campus administration that they could not table the event. They were removed, reprimanded, and threatened with suspension as an on-campus organization ("18 Professors" 1967, 1). This was part of a developing pattern. Later that year SDS members organized a "chalk-in" to protest the arrest of two students for chalking inflammatory things on campus. During the protest SDS members chalked the sidewalks of campus and were verbally reprimanded for using the phrase "In the first place god made idiots. this was for practice. Then he made college administrators" ("Chalk-in" 1967, 1). This caused Congressman Ichord to write to MU Director of Public Information Tom Richter requesting the group be disciplined (Ichord 1967). It also prompted a public dispute in local papers over the right to chalk.

In 1968, SDS members challenged university procedures and policies, further frustrating staff. They planned to stage the play "Macbird," a satire of the Johnson administration, and hoped to charge admission as a fundraiser to purportedly afford bringing Allen Ginsberg to campus. They were denied the ability to charge admission by the university. On May 3, 1968, they were scheduled to go before a student-faculty committee to discuss the issue, but refused to continue after a reporter they arrived with from MU paper The Maneater was asked to leave. In late May an application for use of McAleaster Park for a different program on campus was sent with an attached memo to Chancellor Schwada. The memo emphasized that when questioned by staff receiving the application, SDS members "insisted upon debating" a policy requiring public events to be approved by the chancellor (Department Correspondence 1968). 
Students Walter Grossman and Gerald Waggoner (1969) released a "White Paper" on these events, written "strictly as individuals," analyzing the group's motives and voicing frustrations with the SDS. They connected local SDS tactics directly to a piece they refer to from the national paper New Left Notes, "Toward Student Syndicalism," written by the national vice president of SDS at that time, Carl Davidson. Grossman and Waggoner surmised that "actions of MU SDS seem often more related to this nationally proposed blueprint than to the real issues on this campus," and elaborated, "Davidson advises that SDS should not deal with issues which "can be accommodated by the administration." One tactic described is to "confuse things so that administration could not act effectively, and then blame the administration." This was something the authors saw in the disputes over "Macbird," and the admission price at public events on campus, which became a dispute about the freedom of press at their student-faculty committee hearing. The authors go on to accuse the MU SDS of manufacturing issues and exploiting them for "other than stated reasons," in an act of bad faith.

This strategy, while dubious to some, was no doubt effective in raising the profile of an otherwise disorganized and small organization. In an October 1968 interview with the Columbia Tribune, former SDS president and future Missouri State Representative Rory Ellinger echoed some of the conclusions of the "White Paper," stating, "I don't think in the past that we organized around the problems of students on campus as much as we could have. . . . We're really noted for our disorganization (and) credited with far more than we are, really" ("What Are the Plans" 1968). Ellinger goes on in that interview to pitch his new organization, the Committee of Concerned Students, and to admonish the then-SDS leader Paul Showalter, who was interviewed alongside Ellinger, saying "Paul, you made it sound like S.D.S. would be all radical theatre," in response to Showalter's descriptions of the organization's goals and tactics.

This was indicative of the national state of SDS. In 1965 its members organized a massive "March Against the Vietnam War," which drew 25,000 people to Washington, DC. Potentially misguided attempts at a decentralized organization left it with weak infrastructure and an unclear strategy following this very public success. The organization bloomed to more than 100,000 members, but became highly fractionated and failed to make ground. By 1969 it was dominated by more strict and conflicting ideological Maoist and Maxist-Lenist sects at the national level, leaving local organizations largely on their own with little meaningful direction, divided into conflicting ideological camps (Heideman 2018).

This was reflected in a description of the MU chapter from 1968 as divided into three camps: "liberals," "kamikazes" (ultra-leftists), and "old-timers" whose organizing efforts regularly devolved into "debates . . . heard countless times before" (Sale 1973, 293).

These students were only able to challenge the university by drawing controversy and aggressive pushback-in other words, by being a gadfly. Despite their disorganization, SDS was able to draw the attention of the university over and over again, prompting major public figures to write directly to the university and to newspapers across the state. This news coverage exploded after the February incidents. Coverage in the Missourian from the time includes regular comments directed at board members from Representative Ichord and State Senator Richard Southern, as well as numerous letters to the editor from alumni and citizens. The archival record contains a deluge of personal letters received by Chancellor Schwada.

This public response no doubt influenced Matthews's focused interest in the SDS. The major themes of this relationship are exemplified in an edition of the Free Press Underground published earlier in February of 1969. That February 3 edition carried a letter from Dean Matthews to SDS member Paul Showalter, originally dated December 19, 1968, wherein Matthews describes absolute amazement after reading that Showalter suggested the university be burnt to the ground in a 1968 interview given to The Maneater. Matthews writes,

Paul, I thought I knew you pretty well, I have talked with you on several occasions this fall, and you just didn't appear to me to be the kind of individual that, when certain conditions were not met, would advocate "burning the University." You know, it was about a week ago when a building, a very large building, was burned on the Kansas State Campus. (1969a)

Showalter responds a few pages later in the same Free Press Underground issue:

I, too, am shocked . . . I think we have forgotten what a tremendous privilege it is to attend the University. The student protests over constitutional rights, the "destructive" attempts to make the University democratic, and the over-concern with the University's role in racism and war, overlooks the advantages of a college education. We lose sight of the fact that any one of us, with diligent preparation, can be a prosperous, sensitive human being, even a Dean of Students. $(1969,3)$. 
This back-and-forth provides an excellent microcosm for understanding the rhetorical climate that inspired and allowed for the Papish free speech incident. Showalter's "burn it down" rhetoric was provocative and over-thetop, and in many ways it belied more detailed objections he went on to make in this case, and which his organization and newspaper advocated for consistently. Matthews's response is paternalistic and in the context of real possibility of threat. His statement regarding Kansas State's campus refers to an arson event that caused K-State's Nichol's Hall to burn to the ground in December 1968 (Collegian, 2013).

In an era of student revolt, shortly after a total student takeover on the campus of Columbia University and one of the largest riots in Missouri history in Kansas City following the assassination of Martin Luther King Jr.- both in April of 1968 - and with ongoing public pressure, it would seem the university saw fit to ramp up their effort at containing any possible threat on their campus. The spunky though loosely organized students of SDS and the Free Press Underground continued, as they had throughout their publication history, to advocate for student control of the university and to raise awareness of issues such as homophobia, racism, sexism, and the university's assistance with the war effort. However, in using provocative rhetorical techniques, ultimately they prompted the university to respond with significant force. The act of publishing the cartoon, though perhaps a powerful metaphor for the right to speak freely and its necessity in the democratic environment the students hoped to make within the university, was taken to be an act of profanity just as Showalter's metaphor for rejuvenation as burning was taken to be a call for violence. Both sides employed deliberate misinterpretation and/or overinterpretation of one another and antagonistic rhetoric, thus moving the conversation further and further away from legitimacy, or what some might call "good faith."

The "speech" act of publishing the cartoon was meant to communicate the feeling of suppression at having earlier been kicked out of the Union for peacefully distributing what were seen as subversive materials, but the truly nuanced subversive content of any SDS materials or communications had become overshadowed by provocative elements stealing the limelight. This style garnered them attention but was a double-edged sword. This history of back-and-forth suggests how this confrontation became inevitable, and how in many ways SDS provided the university with the tools to dismantle it, while the university took increasingly severe steps to punish a threat that looks minor in hindsight.

\section{Conclusion}

The Papish/Free Press Underground free speech incident represents a turning point in free speech on the college campus, and in the historical development of the 60s protest movement. It predates but is not far from the incendiary speech acts that regularly make the news today. The historical context of the image and the incident present the convergence of free speech controversy and provocative rhetoric that has always been a rich part of politics. The most obvious or evocative read of these situations, though, may very well obscure complex power relationships and struggles that are of value in understanding and furthering the cause of intellectual freedom and preparing others to responsibly consume information. The full historical record provides a depth of meaning to these incidents from which historical, cultural, and social value may be derived, allowing us to see past blunted reactions and quick interpretations to construct a fuller examination of underlying realities, which may then better inform how we approach difference and responsibly process controversial or divisive speech.

Barbara Papish won her case, but the SDS was barely in existence by 1973, and the war in Vietnam would continue for two more years (Heiderman 2018). The speech act in which she was involved as a publisher of the Free Press Underground would add to the precedents for freedom of speech in America, and though it would attract attention, it would do little to articulate and advance the ambitions or frustrations of her and her peers. This case can be extrapolated into a lesson on the fact that freedom does not guarantee the ability to understand and be understood, and analysis of this case presents an opportunity for professionals concerned with intellectual freedom to adjust their purview to reconcile that distinction through historical details and context. 


\section{References}

“18 Professors Protect University Action on SDS." 1967. Columbia Missourian, October 16, 1969. http://cdm16795.contentdm .oclc.org/cdm/compoundobject/collection/colmo2/id /44297/rec/243.

Allain, Alex, Edwin Castagna, and Florence DeHart. 1970. "Proceedings and Findings: Pertaining to a Request for Action Submitted by Mrs. Joan Bodger under the Program of Action in Support of the Library Bill of Rights." American Libraries 1, no. 7: 694-704. https://www.jstor.org/stable/25618002.

"Chalk-In Set At Courthouse For Monday." 1967. Columbia Missourian, April 13. http://cdm16795.contentdm.oclc.org/cdm /compoundobject/collection/colmo2/id/114440/ec/87.

Cieciorka, Frank, and Marvin Garson. 1969. "With Liberty and Justice For All.” The Movement, February.

Collegian, The. 2013. " Friday marks 45th Anniversary of Nichols Gym fire." Kstate Collegian, December 12. https://www.kstate collegian.com/2013/12/12/friday-marks-45th-anniversary -of-nichols-gym-fire/.

Department Correspondence. 1968. Collection C:1/25/1, Box 15, Folder 11, Correspondence Accompanying Park Use Application. UMC; Administration; Vice Chancellor for Student Affairs; Administrative and Other Records. University of Missouri Archives, Columbia, MO.

Committee Conclusion. Faculty Committee on Student Organizations, Government and Activities. 1969. Collection UW: 4/0/3, Box 6, Folder 19, UM-System; President's Office; Administrative Correspondence, University of Missouri Archives, Columbia, MO.

Free Press Underground. February 13, 1969.

Grossmann, Walter, and Gerald Waggoner. 1969. "White Paper." Collection UW:4/141/2, Folder 9, UM-System; President's Office; University Relations; Administrative, Media Relations, and Printed and Duplicated Records. UW:4/141/2 Folder 9. Missouri Archives, Columbia, MO.

Heideman, Paul. 2018. "Half the Way With Mau Zedong." Jacobin 29 (Spring): 66-79.

Ichord, Richard. 1967. "Letter forwarded to Tom Richer." Collection UW:4/141/2, Folder 3, UM-System; President's Office; University Relations; Administrative, Media Relations, and Printed and Duplicated Records. University of Missouri Archives, Columbia, MO.

Kurlansky, Mark. 2005. 1968. New York: Random House Trade Paperbacks.

Matthews, Jack. 1969a. "Mr. Paul Showalter." Free Press Underground, February 3, 1969.
—_ _ 1969b. "Notice Sent to the Students Who Distributed SDS Literature." Collection UW:4/0/3, Box 5, Folder 10. UM-System; President's Office; Administrative Correspondence. University of Missouri Archives, Columbia, MO.

- 1969c. "Petition for Review of Decision of Committee on Student Organizations, Government, and Activities. Collection UW:4/0/3, Box 6, Folder 19. UM System; President's Office; Administrative Correspondence. University of Missouri Archives, Columbia, MO.

Miller, Bob. 1969. "SDS Will Protest at M.U. Monday." Columbia Missourian, February 20, 1969. http://cdm16795.contentdm .oclc.org/cdm/compoundobject/collection/colmo3/id/8505 $/ \mathrm{rec} / 43$.

“Miss Papish is Expelled By University." 1969. Columbia Missourian, March 29, 1969. http://cdm16795.contentdm.oclc.org/cdm /compoundobject/collection/colmo3/id/3562/rec/24.

Perlstein, Rick. 2008. Nixonland: The Rise of a President and the Fracturing of America. New York: Scribner.

Sale, Kirkpatrick. 1973. SDS: The Rise and Development of the Students for a Democratic Society. New York: Vintage Books. https://archive.org/details/sds_kirkpatrick_sale/mode/2up.

"SDS Ousted From Union.” 1969. Columbia Missourian, February 13, 1969. http://cdm16795.contentdm.oclc.org/cdm/com poundobject/collection /colmo3/id/6723/rec/37.

Silvestri, Lisa Ellen. 2018. "Memeingful Memories and the Art of Resistance.” New Media \& Society 20(11): 3997-4016. https:// doi-org.proxy.mul.missouri.edu/10.1177/1461444818766092.

Showalter, Paul. 1969. "Showalter Answers." Free Press Underground, February 3, 1969.

Smith, Michael, and Seth Smith. 2018. "Chronicles of Discontent, Tribunes for Change Columbia and Its Underground Press in the Vietnam Era." Missouri Historical Review 112(3): 207-23.

Steele, Don. 1969. "Matthews Tells SDS Officers to Appear Before Committee." Columbia Missourian, February 14. http://cdm 16795.contentdm.oclc.org/cdm/compoundobject/collection /colmo3/id/7246/rec/38.

"Supreme Court of the United States: Barbara Susan Papish v. The Board of Curators of the University of Missouri et al." March 19, 1973. https://eric.ed.gov/?id=ED080071.

"What Are the Plans of S.D.S. on M.U. Campus." 1968. Columbia Tribune, October 13. Collection UW:4/141/2 Folder 9 University Relations; Administrative, Media Relations, and Printed and Duplicated Records. University of Missouri Archives, Columbia, MO. 